\title{
INKLUSI SOSIAL DALAM PEMBANGUNAN DESA
}

\author{
Prima Putra Budi Gutama; Bambang Widiyahseno \\ Program Studi Ilmu Pemerintahan Fakultas Ilmu Sosial dan Ilmu Politik \\ Universitas Muhammadiyah Ponorogo \\ Email: primap711@gmail.com; bbwidiyahseno@umpo.ac.id
}

\begin{abstract}
Abstrak: Penelitian ini dilakukan dengan dasar tujuan untuk mengetahui bagaimana inklusi sosial dijalankan dalam pembangunan desa yang mana penekanan inklusi sosial ditujukan untuk masyarakat rawan eksklusi (marginalisasi). Adapun rumusan masalah dalam artikel ini diantaranya; bagaimana konsep inklusi sosial dalam pembangunan desa, bagaimana konsep masyarakat marginal, bagaimana konsep siklus pembangunan desa, serta bagaimana realitas inklusi sosial dalam siklus pembangunan desa. Metode yang digunakan adalah metode deskriptif kualitatif dengan data berbasis kajian undang-undang, kajian kepustakaan serta data empiris realitas. Teknik analisis data yang digunakan pada penelitian ini adalah teknik analisis kualitatif dimana data-data yang diperoleh dianalisis dengan tahapan mereduksi data, menyajikan data, dan manarik kesimpulan. Hasil kajian dari penelitian ini berdasar data lapangan inklusi sosial yang dijalankan dalam pembangunan desa di Desa Tempuran adalah kebijakan pembangunan membawa masyarakat untuk inklusi (terlibat) dalam pembangunan desa yang mengarah pada pemenuhan hak masyarakat, ekonomi masyarakat, kepartisipasian masyarakat, dan pemberdayaan masyarakat, namun terkendala oleh kelambatan rekonstruksi sarana dan prasarana serta tidak ada pembaharuan atau inovasi yang dikembangkan dalam komoditas home industry (Industri Rumahan) masyarakatnya. Hal tersebut berimbas pada tidak maksimalnya perkembangan atau dinamika inklusi sosial dalam pembangunan desa yang dilakukan masyarakat Desa Tempuran.
\end{abstract}

\section{Kata kunci: Inklusi sosial, pembangunan desa.}

\begin{abstract}
This research was carried out on the basis of the aim to find out how social inclusion was carried out in village development where the emphasis on social inclusion was aimed at vulnerable communities of exclusion (marginalization). The formulation of the problems in this article include; how is the concept of social inclusion in village development, what is the concept of marginal society, what is the concept of the village development cycle, and how the reality of social inclusion in the village development cycle. The method used is a qualitative descriptive method with data based on the study of laws, literature studies as well as empirical data on reality. Data analysis technique used in this study is a qualitative analysis technique where the data obtained are analyzed with the stages of reducing data, presenting data, and draw conclusions. The results of this study are based on social inclusion field data carried out in village development in Tempuran Village development policies bring the community to inclusion (involved) in village development that leads to the fulfillment of community rights, the community's economy, community participation, and community empowerment, but constrained by the slow reconstruction of facilities and infrastructure and no renewal or innovation developed in commodities home industry (Industri Rumahan) of the cmmunity, this has an impact on the non optimal development or dynamics of social inclusion in rural development by the people of Tempuran Village.
\end{abstract}

Keywords: Social inclusion, village development

\section{PENDAHULUAN}

Pembangunan desa merupakan bagian integral dari pembangunan nasional. Hal ini menjadikan pembangunan desa sebagai lokus pembangunan yang tidak luput dari perhatian pemerintah baik pemerintah pusat maupun pemerintah daerah. Melalui peregulasian terhadap desa dan pembangunannya secara yuridis formal yaitu Undang-Undang Nomor 6 Tahun 2014 Tentang Desa (selanjutnya disebut dengan "Undang-Undang Desa"), menjadikan desa sebagai wilayah yang dikelola dengan pembangunan berstandar undang-undang tersebut. Dalam undang-undang desa disampaikan pada ketentuan umumnya bahwa: 


\section{REFORMASI}

ISSN 2088-7469 (Paper) ISSN 2407-6864 (Online)

Volume 10 Nomor 1 (2020)

"Pembangunan Desa adalah upaya peningkatan kualitas hidup dan kehidupan untuk sebesar-besarnya kesejahteraan masyarakat Desa." (Sumber : Undang-Undang Nomor 6 Tahun 2014 Tentang Desa).

Adapun tujuan dari pembangunan desa, merupakan muara akhir dari pembangunan desa yang ditetapkan dalam Undang-Undang Desa. Dalam Undang-Undang Desa tersebut diterangkan melalui pasal 78 ayat 1 yang menyatakan:

"Pembangunan Desa bertujuan meningkatkan kesejahteraan masyarakat desa dan kualitas hidup manusia serta penanggulangan kemiskinan melalui pemenuhan kebutuhan dasar, pembangunan sarana dan prasarana Desa, pengembangan potensi ekonomi lokal, serta pemanfaatan sumber daya alam dan lingkungan secara berkelanjutan.”(Sumber : Undang-Undang Nomor 6 Tahun 2014 Tentang Desa).

Pada Undang-Undang Desa diatur bahwa masyarakat memiliki peranan sebagai subjek pembangunan. Namun tidak dipungkiri bahwa pada kehidupan masyarakat masih terdapat adanya potensi eksklusi sosial atau marginalisasi sosial yang melemahkan peran masyarakat sebagai subjek pembangunan. Eksklusi sosial dikemukakan oleh Paul Francis, Rawal (dalam Simarmata, 2017:9) sebagai upaya yang menjadikan seseorang atau kelompok tertentu untuk tidak bisa ikut berperan dalam kehidupan sosial, baik sebagaian ataupun penuh. Proses ini ada karena berbagai hal seperti pengangguran, kemiskinan, tidak adanya jaringan untuk pendukung sosial, tidak ada akses layanan umum, serta pengaruh lingkungan sosial dan tempat tinggal, seperti yang dikemukakan Pierson (dalam Maftuhin, 2017:97) bahwa hal-hal tersebut dapat memperparah ekslusi atau marginalisasi. Bila hal tersebut terjadi dalam suatu desa maka akan menghambat tercapainya tujuan pembanguan desa.

Terdapat beberapa penelitian terdahulu yang mengaitkan inklusi sosial dengan pembangunan desa. Pada penelitian yang dilakukan Dekki Umamur Ra'is (2017) dengan karya ilmiahnya yang berjudul "Peta Inklusi Sosial dalam Regulasi Desa" menghasilkan kesimpulan bahwa inklusi sosial adalah salah satu tujuan yang dibawa dalam Undang-Undang Desa, yang memiliki arah untuk membuat kemiskinan berakhir, mendorong kebersamaan masyarakat dalam kemakmuran dan menstimulasi keterlibatan segenap warga desa dalam kehidupan masyarakat. Kemudian ada penelitian berjudul"Perspektif Inklusi Sosial dalamUU Nomor 6 Tahun 2014 tentang Desa: Kebijakan dan Tantangan Implementas", karya dari Rikardo Simarmata dan R. Yando Zakaria (2017) yang menyatakan bahwa masih terdapat kelemahan pada Undang-Undang Desa dalam membawa inklusi sosial dan perlu menjadikan inklusi sosial sebagai perspektif yang berlaku menyeluruh, menegaskan cakupan yang menjadi kelompok marginal dan menegaskan serta meluaskan jaminan-jaminan yang ditujukan untuk kelompok marginal. Hal ini menunjukkan betapa pentingnya inklusi soial dalam pembangunan desa guna menghapus eksklusi pada masyarakat sehingga tujuan dari pembangunan desayang dicita-citakan dalam Undang-Undang Desa dapat tercapai bagi seluruh lapisan masyarakat desa.

Ponorogo adalah kabupaten yang memiliki beberapa desa dengan penduduk yang rawan ekslusi. seperti desa dengan penduduknya yang merupakan penyandang disabilitas yang diantaranya yaitu Desa KarangpatihanKecamatan Balong, Desa Sidoharjo Kecamatan Jambon, Desa Kerebet Kecamatan Jambon dan beberapa desa lainnya. Diantara desa-desa tersebut juga ada yang cukup mahsyur terkenal sebagai "kampung idiot" dan menjadi salah satu destinasi wisatadi Kabupaten Ponorogo. Hal tersebut menunjukkan bahwa telah ada inklusi sosial yang diinternalisasikan dalam pembangunan desanya. Namun tidak semua desa yang memiliki penduduk rawan tereksklusi bisa terakomodir kehidupan dan kualitas hidupnya meskipun telah melakukan inklusi sosial hal tersebut menarik untuk diungkap apa penyebabnya. Salah satu desa yang menjalankan inklusi sosial namun memiliki peradaban statis 


\section{REFORMASI}

ISSN 2088-7469 (Paper) ISSN 2407-6864 (Online)

Volume 10 Nomor 1 (2020)

adalah Desa Tempuran. Desa Tempuran berada di kecamatan Sawoo yang merupakan bagian timur Kabupaten Ponorogo dan merupakan salah satu desa di Kabupaten Ponorogo yang berbatasan dengan Kabupaten Trenggalek. Desa Tempuran memiliki jarak $12 \mathrm{Km}$ dari ibu kota kecamatan dan $33 \mathrm{Km}$ dari ibu kota kabupaten. Pada demografisnya, penduduk Desa Tempuran didominasi dengan sumber daya manusia yang secara jenjang pendidikannya kebanyakan tamatan sekolah dasar, dan dalam hal profesi kebanyakan bermatapencaharian dalam bidang pertanian. Hal demikian ini membawa masyarakat Desa Tempuran memiliki keadaan terisolir, sulit untuk mengakses layanan kesehatan, serta sulit mengembangkan perekonomian. Mengingat bahwa Undang-Undang Desamemuat inklusi sosial dan bila pemerintah desa telah menjalankannya, makabila masyarakat Desa Tempuran masih berada dalam keadaan demikian sulit untuk mencapai tujuan yang dicita-citakan dalam UndangUndang Desa, maka kemungkinan yang terjadi adalah adanya halangandalam memaksimalkan inklusi sosial dalam pembangunan desa.

Dengan dasar bahwa inklusi sosial harus terwujud dalam pembangunan desa,kemudian masih adanya desa dengan penduduk rawan eksklusi pada Desa Tempuran, penulis memiliki tujuan untuk mengetahui seberapa jauh inklusi sosial dilaksanakan dalam pembangunan desa di Desa Tempuran dengan melakukan penelitian yang berjudul "Inklusi Sosial dalam Pembangunan Desa (Studi Pada Desa Tempuran Kecamatan Sawoo Kabupaten Ponorogo)”.

\section{METODE PENELITIAN}

Penelitian ini menggunakan metode analisis deskriptif kualitatif yang berarti merupakan penelitian yang menyajikan data bukan dalam bentuk angka-angka melainkan deskripsi tertulis berdasar observasi, wawancara, serta dokumentasi. Usman (dalam Walmi Sholihat, 2017:19) menyampaikan bahwa Penelitian Kualitatif adalah penelitian yang pengumpulan datanya, pengolahan datanya, pembuatan laporannya, serta penarikan kesimpulannya bersumber dari data yang didapatkan dari observasi, wawancara, dan dokumentasi. Observasi adalah metode penggalian data melalui pengamatan dengan inderawi langsung terhadap benda, situasi, keadaan, proses atau perilaku (Fitrah, 2017:20). Observasi pada penelitian ini dilakukan dalam teritorial Desa Tempuran. Wawancara merupakan proses membangun pemahaman terhadap orang, peristiwa, aktivitas, organisasi dan sebagianya yang prosesnya melibatkan dua pihak, yaitu pihak interviewer (penanya) dan narasumber atau pihak yang diwawancarai (Arum, 2019:18). Pihak yang diwawancari dalam penelitian ini adalah pemerintah desa dan masyarakat DesaTempuran, serta Bhabinkamtibmas Desa Tempuran. Dokumentasi merupakan metode pengumpulan data yang dilakukan dengan cara mengambil dokumen ataupun foto-foto yang memiliki keterkaitan dengan penelitian (Henra Natalia Silaban \& Setiawan, 2016:13)

Prosesnya dimulai dari saat sebelum terjun ke lapangan, selama berada di lapangan, dan setelah usai dari lapangan. Sebelum ke lapangan peneliti terlebih dahulu menentukan penetapan standar objek penelitian yang akan dikaji dimana dalam penelitian ini objek kajiannya adalah pembangunan desa dengan standar berupa desa yang menerapkan inklusi sosial, selama berada dilapangan peneliti melakukan observasi, wawancara, dan dokumentasi secara interaktif dan terus-menerus hingga data yang diperoleh telah mencapai kondisi jenuh, setelah diperolehnya data-data dari lapangan, selanjutnya peneliti melakukan analisis data secara kualitatif dengan mereduksi data (data reduction), menyajikan data (data display), dan manarik kesimpulan (conclusion drawing). Miles dan Huberman (dalam Kushandajani, 2019:230) memaparkan bahwa teknik analisis kualitatif terdiri dari beberapa tahapan, yaitu data reduction atau reduksi data, data display atau penyajian data, dan conclusion drawing atau penarikan kesimpulan. 


\section{REFORMASI}

ISSN 2088-7469 (Paper) ISSN 2407-6864 (Online)

Volume 10 Nomor 1 (2020)

\section{KAJIAN PUSTAKA}

Pada penelitian ini, penulis menggali informasi melalui beberapa penelitian terdahulu guna sebagai perbandingan pada penelitian yang dilakukan peulis, sekaligus untuk memahami keunggulan dan kelemahan pada masing-masing penelitian yang sudah ada sehigga pada penelitian penulis ini mampu menjadi penelitian yang bersifat progresif terhadap fokus yang terkait dengan penelitian sebelumnya. Ada dua unsur pokok yang dikaji melalui penelitian penulis, yaitu inklusi sosial dan pembangunan desa, dua unsur tersebut telah dimuat dalam beberapa penelitian sebelumnya, yaitu :

1. Dekki Umamur Ra'is, mahasiswa Program Studi Ilmu Administrasi Negara, Fakultas Ilmu Sosial dan Ilmu Politik, Universitas Tribhuwana Tunggadewi Malang dengan karya ilimiahnya tahun 2017 yang berjudul "Peta Inklusi Sosial dalam Regulasi Desa".

Penelitian ini memiliki ruang lingkup pembahasan berbasis regulasi desa mencakup UndangUndang Desa dan beberapa Peraturan Menteri Dalam Negeri. Menyajikan beberapa pokok pembahasam diantaranya inklusi sosial desa, pembangunan partisipatif, peluang dan tantangan, dan masa depan masyarakat desa. Disajikan dengan metode analisis deskriptif kualitatif, namun tidak menampilkan studi lapangan, sehingga pokok-pokok pembahasan yang ditampilkan berdasar kajian pustaka baik buku dan karya ilmiah terdahulu dan kajian berbasis undang-undang. Kesimpulan dari penelitiannya menyebutkan bahwa inklusi sosial merupakan bagian dari tujuan Undang-Undang Desa (Undang-Undang Nomor 6 Tahun 2014 tentang Desa) dan pada Undang-Undang Desa terdapat amanah bahwa pembangunan desa perlu dilakukan secara partisipatif.

2. Karya ilmiah yang berjudul "Perspektif Inklusi Sosial dalam UU Nomor 6 Tahun 2014 tentang Desa: Kebijakan dan Tantangan Implementasi”, merupakan karya ilmiah dari Rikardo Simarmata (Dosen Fakultas Hukum, Universitas Gadjah Mada, Yogyakarta) dan R. Yando Zakaria (Praktisi antropologi Lingkar Pembaruan Desa dan Agraria (KARSA), Yogyakarta).

Penelitian ini memiliki beberapa tiga pokok pembahasan dengan ruang lingkup kajian terhadap Undang-Undang Desa. Pokok-pokok pembahasannya diantaranya yaitu kerangka hukum dan kebijakan sosial, kualitas pengaturan inklusi sosial dalam uu desa, pandangan dan dinamika inisiatif promosi perspektif dan program inklusi sosial, arah kebijakan dan program ke depan, serta beberapa rekomendasi strategis. Kesimpulan dari penelitian tersebut menyatakan bahwa UndangUndang Desa belum sepenuhnya menjadikan inklusi sosial sebagai perspektif, Undang-Undang Desa tidak secara ekspilsit menyebutkan "kelompok marginal", serta Undang-Undang Desa tidak menyediakan jaminan akan keterlaksanaan inklusi sosial.

Pada Kedua penelitian tersebut sama-sama menampilkan inklusi sosial yang disandingkan dengan Pembangunan desa yang diperkuat dengan kajian pustaka dan kajian terhadap beberapa regulasi terkait, belum terdapat keterangan demensi dan ruang lingkup yang perlu dibidik dalam menghapus marginalisasi dalam pembangunan desa melalui inklusi sosial. Pada penelitian yang dilakukan penulis ini akan menyajikan pembahasan dengan menggunakan teroi demensi marginalisasi dari Alfitri (dalam Auldina, 2018:3), guna menjelaskan demensi perjuangan yang hendak dicapai masyarakat marginal, kemudian menyandingkan dan mengkorelasikannya kepada lingkup pembangunan desa yang didasarkan pada yuridis formal terkait. Penelitian ini juga menyertakan studi lapangan dalam sekup desa dengan kategori desa yang memiliki demografis masyarakat rawan tereksklusi dalam pembangunan desa. Sehingga sisi terbaru dari penelitian ini adalah terdapatnya teori penjelasan demensi marginalisasi, serta relevansi demensi marginalisasi terhadap ruang lingkup pada pembangunan desa, yang disertai studi lapangan dalam mengetahui realitasnya. 


\section{REFORMASI}

ISSN 2088-7469 (Paper) ISSN 2407-6864 (Online)

Volume 10 Nomor 1 (2020)

\section{PEMBAHASAN}

\section{Konsep inklusi sosial dalam pembangunan desa.}

Inklusi sosial dalam pembangunan desa merupakan nilai yang mengarahkan masyarakat kepada dua bentuk pergerakan, yaitu pergerakan masyarakat sebagai subjek pembangunan secara regulatif berdasar undang-undang dan pergerakan masyarakat sebagai subjek yang mengikis marginalisasinya. Antara keduanya saling berkaitan dimana posisi masyarakat sebagai subjek yang mengikis marginalisasinya merupakan bagian integral dari peranan masyarakat dalam menjadi sebagai subjek pembangunan berdasar yuridis formalnya. Hal ini didasarkan secara teoritis dan undang-undang.

Secara teoritis inklusi sosial adalah proses yang memberikan daya pada individu atau kelompok tertentu untuk ikut berpartisipsi dalam kehidupan sosial baik secara menyeluruh ataupun sebagian (Simarmata, 2017:9). Pendefinisian terhadap inklusi sosial tersebut merupakan keterbalikan dari eksklusi sosial, ekslusi sosial merupakan keadaan dimana terjadi pemisahan terhadap komunitas tertentu atau individu tertentu yang menyebabkan timbulnya dampak berupa hilangnya kemampuan dan daya pada komunitas atau individu tertentu tersebut untuk bisa membaur dengan masyarakat umum dalam berbagai urusan kemasyarakatan. Secara garis besar timbulnya eksklusi sosial ini disebabkan adanya perbedaan latar belakang baik status sosial, perbedaan pandangan, atau apapun yang mengundang terjadinya marginalisasi dalam masyarakat (Ningrum, 2019:125).

Secara yuridis formal inklusi sosial dalam kaitannya terhadap masyarakat sebagai subjek pembanguan, tertuang Pada Undang-Undang Nomor 6 Tahun 2014 tentang Desa. Dalam undangundang tersebut terdapat beberapa muatan nilai inklusi sosial; pertama yaitu adanya pengakuan kepada masyarakat hukum adat untuk dipersilahkan menyelenggarakan pemerintahan yang didasarkan dan sesuai dengan hak asal-usul serta susunan asli (asas subsidiaritas); kedua, inklusi sosial dalam Undang-Undang Desa adalah diberikannya kesempatan kepada penduduk miskin serta perempuan untuk berpartisipasi dalam penyelenggaraan pemerintahan secara umum dan pembangunan desa; sedangkan yang ketiga dimuarakan kepada seluruh warga desa secara umum untuk ikut berpartisipasi dalam penyelenggaraan pemerintahan, perencanaan, penataan dan pembangunan desa (Simarmata, 2017:10).

Pada pendefinisannya, pemahaman terhadap inklusi sosial sekilas mirip dengan makna pemberdayaan, bahkan juga memiliki keterkaitan dengan penegakkan HAM dan partisipasi. Hal tersebut terjadi karena muatan dalam nilai inklusi sosial memuat pemberdayaan, penegakkan HAM, dan partisipasi. Tyahta Supriyatna (dalam Yulisnaini, 2018:9) mengemukakan bahwa pemberdayaan merupakan kegiatan yang berusaha untuk membangun kemandirian serta jati diri manusia atas sumberdaya kemanusiaannya yang berupa kemampuan dan kekuatan untuk hidup melalui proses pembinaan dan bantuan teknis maupun bimbingan. Makna pemberdayaan tersebut sejalan dengan konsepsi inklusi sosial yang mengarah adanya kemampuan dan daya bagi masyarakat rawan marginal. Sedangkan keterkaitan antara inklusi sosial dengan HAM adalah bahwa dalam inklusi sosial terkandung nilai untuk memperjuangkan hak kemanusiaan individu atau masyarakat yang rawan termaginalkan atau terdiskriminasi dalam masyarakat, dimana masyarakat marginal merupakan individu-individu atau mereka yang masuk kedalam keadaan terpinggirkan untuk mendapat akses atas keadilan, disebabkan bermacam keterbatasan yang mereka miliki (Fahadi, 2020:15). Sedangkan partisipasi memiliki keterkaitan dengan inklusi sosial dikarenakan inklusi sosial berusaha menghadirkan kondisi dimana individu atau keompok tertentu yang rawan tereksklusi mampu berperan dalam lingkungan masyarakatnya dan partisipasi sejalan dengan hal yang demikian karena partisipasi merupakan aktivitas atau kegiatan yang mana terdapat keterlibatan kelompok atau individu dalam upaya mencapai tujuan serta terdapat adanya pembagian kewenangan atau tanggungjawab bersama dalam kegiatan tersebut (Dadan Rohimat, Rita Rahmawati, 2017:75). Hal tersebutlah yang 


\section{REFORMASI}

ISSN 2088-7469 (Paper) ISSN 2407-6864 (Online)

Volume 10 Nomor 1 (2020)

menjadikan adanya korelasi antara inklusi sosial dengan pemberdayaan, inklusi sosial dengan penegakkan HAM, serta inklusi soial dengan partisipasi, namun penekanan inklusi sosial diarahkan kepada individu atau kelompok yang rawan mengalami eksklusi sosial atau marginalisasi sosial disebabkan keterbatasan yng mereka miliki. Inklusi sosial ini kemudian menjadi nilai perjuangan dalam pembangunan desa, mengingat bahwa desa merupakan wadah bagi hajat hidup masyarakat desa dengan berbagai keadaannya, baik potensi atau keterbatasannya.

Berdasar pemaparan secara teoritis dan yuridis formalnya, maka inklusi sosial merupakan upaya untuk memeberi dorogan masyarakat rawan marginalisasi menuju kesejahteraan, bukan merupakan hasil atau kesejahteraan itu sendiri. Dalam pembangunan desa dapat dimaknai bahwa inklusi sosial sebagai nilai memperjuangkan masyarakat yang rawan marginalisasi untuk mencapai kondisi idealnya dan menjadi subjek pembangunan dalam pembangunan desa.

\section{Konsep masyarakat marginal / masyarakat tereksklusi.}

Alfitri (dalam Auldina, 2018:3) mengemukakan bahwa untuk memahami masyarakat marginal bisa dilihat melalui tiga demensi. Pertama, yaitu demensi ekonomi, demensi ini menerangkan keadaan masyarakat mengalami marginal karena tidak dapat memperoleh pekerjaan disebabkan adanya kriteria-kriteria atau syarat untuk mendapat pekerjaan yang mana tidak dimiliki oleh masyarakat tersebut. Kedua, yaitu demensi politik dan administrasi publik, demensi ini membawa pemahaman bahwa masyarakat yang mengalami marginal tidak diikut sertakan kedalam politik dan merekapun sulit untuk mendapat kemudahan-kemudahan dari pemerintah. Ketiga, yaitu demensi kemudahan fisik yang terhalang karena keterbatasan dalam aksesbilitas, maksud dari demensi ini adalah masyarakat yang mengalami marginalisasi, sulit mendapat kemudahan secara fisik seperti layanan akses teknologi, komunikasi, air bersih, bantuan kesehatan, listrik, pendidikan dan lai-lain.

Pierson (dalam Maftuhin, 2017:97) menyebutkan bahwa ada lima komponen penting dalam eksklusi sosial, yaitu pengangguran, kemiskinan, tidak adanya jaringan untuk pendukung sosial, tidak ada akses layanan umum, serta pengaruh lingkungan sosial dan tempat tinggal. Dia berpendapat bahwa kelima hal tersebut saling berkaitan dan meninkatkan keparahan eksklusi.

Berdasarkan uraian diatas maka dapat diketahui dan dipahami bahwa masyarakat marginal adalah masyarakat yang memiliki perjuangan akibat keterbatasannya pada demensi ruang publik, ekonomi, dan juga aksesbilitas layanan umum, serta hal-hal lain yang menjadi haknya.

\section{Konsep pembangunan desa.}

Pembangunan desa memiliki dua pengertian, yaitu pengertian secara luas dan pengertian secara sempit. Pebangunan desa dalam arti luas, dipahami sebagai upaya meningkatkan kualitas hidup dan kehidupan yang mengarah pada kesejahteraan masyarakat Desa sebagaimana penjelasan pada ketentuan umum dalam Undang-Undang Desa (Sumber: Undang-Undang Nomor 6 Tahun 2014 Tentang Desa). Sedangkan pembangunan desa dalam arti sempit diukur secara materi, diterangkan sebagai salah satu bidang pada lingkup pembangunan desa yang tertuang dalam Rencana Pembangunan Jangka Menengah Desa (RPJMDes) (Sumber: Peraturan Menteri Dalam Negeri Republik Indonesia Nomor 114 Tahun 2014 tentang Pedoman Pembangunan Desa)

Pembangunan desa memiliki tahapan yang kemudian menjadi siklus dalam pembangunan desa. Siklus pembangunan desa merupakan tahapan pembangunan desa yang terjadi secara terus berulangulang secara beriringan. Tahapan tersebut disampaikan dalam Undang-Undang Desa pada pasal 78 ayat 2 sebagai berikut :

"Pembangunan Desa meliputi tahap perencanaan, pelaksanaan, dan pengawasan." (Sumber: Undang-Undang Nomor 6 Tahun 2014 tentang Desa). 


\section{REFORMASI}

ISSN 2088-7469 (Paper) ISSN 2407-6864 (Online)

Volume 10 Nomor 1 (2020)

Penjabaran dari siklus pembangunan desa tersebut terbinkai lebih rinci melalui Peraturan Menteri Dalam Negeri Republik Indonesia Nomor 114 Tahun 2014 tentang Pedoman Pembangunan Desa. Regulasi tersebut menjelaskan bahwa pembanguna desa memiliki tiga tahapan yaitu perencanaan, pelaksanaan, dan pengawasan, sedangkan lingkup dari pembangunan desa diantaranya adalah bidang penyelenggaraan pemerinatahan desa, bidang pelaksanaan pembangunan desa, bidang pemberdayaan masyarakat desa, dan bidang pembinaan masyarakat desa. Hubungan antara siklus pebangunan desa dengan lingkup pembangunan desa adalah hubungan dimana siklus pembangunan desa menjadi wadah aksi dari lingkup pebangunan desa.

Pembangunan desa dimulai dari tahap perencanaan pembangunan. Pada tahap prencanaan pembangunan desa, perencanaan pembangunan dimanifestasikan menjadi dokumen RPJMDes (Rencana Pembangunan Jangka Menengah Desa) dan RKPDes (Rencana Kerja Pemerintah Desa). RPJMDes adalah rencana pembangunan yang berlaku untuk enam tahun yang mana ditetapkan paling lama tiga bulan sejak pelantikan kepala desa, sedangkan RKPDes berlaku untuk satu tahun, disusun muli bulan juli tahun berjalan dan paling lambat ditetapkan pada bulan september tahun berjalan. Baik RPJMDes dan RKPDes memuat lingkup pembangunan yang saling berkaitan, sebab RKPDes merupakan bagian atau penjabaran pertahun dari RPJMDes.

Setelah tahap perencanaan pembangunan desa, pembangunan desa kemudian berlanjut pada tahap pelaksanaan. Pada tahap ini terdapat dua macam pembangunan, yaitu pembangunan desa berskala lokal desa dan pembangunan pembangunan sektoral dari daerah yang masuk ke desa. Tahap pelaksanaan ini dimulai sejak ditetapkannya APBDes dimana kepala desa mengoordinasikan persiapan dan pelaksanaan pembangunan desa.

Adanya tahap perencaaan dan pelaksanaan dalam pembangunan desa, juga diiringi tahap pengawasan pembangunan desa. Tahapan ini memberi masyarakat dan pemerintah kabupaten/kota sebagai pengawas dan pemantau dalam pembangunan desa. Bagi masyarakat, pemantauan dilakukan pada tahap perencnaan dengan menilai penyusunan RPJMDes dan RKPDes kemudian pada tahap pelaksanaannya, masyarakat memantau dengan cara menilai pengadaan barang, jasa, terial, tenaga kerja, tata kelol keuangan, pengiriman materil, pembayaran upah, dan kualitas hasil kegiatan pembangunan desa, yang selanjutnya dituangkan dalam format hasil pemantauan pada pembangunan desa. Bagi pemerintah kabupaten/kota, pemantauan dan pengawasan dilakukan dengan memantau dan mengawasi jadwal perencanaan dan pelaksanaan pembangunan desa, menerima dan mempelajari serta memberikan umpan balik terhadap laporan realisasi APBDes, kemudian mengevaluasi perkembangan serta kemajuan kegiatan pebangunan desa, seain itu memberikan bimbingan teknis kepada pemerintah desa (Sumber: Permendagri Nomor 114 Tahu 2014 tentang Pedoman Pembangunan Desa).

\section{Analisis dan realitas inklusi sosial dalam pembangunan desa di DesaTempuran.}

Secara administratif wilayah Desa Tempuran Memiliki 4 Dusun, 19 RW, 54 RT, 1793 KK dengan Jumlah penduduk Laki-laki mencapai 3207 orang, serta penduduk perempuan mencapai 3045 orang. Adapun keadaan penduduk Desa Tempuran berdasar klasifikasi sumber daya manusia secara strata pendidikan dan matapencaharian yang tercatat oleh Pemerintah Desa Tempuran sebagaimana berikut ini. 


\section{REFORMASI}

ISSN 2088-7469 (Paper) ISSN 2407-6864 (Online)

Volume 10 Nomor 1 (2020)

Tabel 1. Data Tingkat Pendidikan Penduduk Desa Tempuran

\begin{tabular}{|l|l|l|l|}
\hline No. & \multicolumn{1}{|c|}{ Tingkatan Pendidikan } & \multicolumn{1}{c|}{ Laki-laki } & \multicolumn{1}{c|}{ Perempuan } \\
\hline 1 & Tamat SD/sederajat & 2052 orang & 1990 orang \\
\hline 2 & Tamat SMP/sederajat & 174 orang & 168 orang \\
\hline 3 & Tamat SMA/sederajat & 21 orang & 22 orang \\
\hline 4 & Tamat D-1/sederajat & 3 orang & 4 orang \\
\hline 5 & Tamat D-3/sederajat & 4 orang & - \\
\hline 6 & Tamat S-1/sederajat & 20 orang & 6 orang \\
\hline 7 & Tamat S-2/sederajat & 2 orang & - \\
\hline
\end{tabular}

(Sumber: dokumentasi dari profil Desa Tempuran 2019)

Tabel 2. Data Penduduk Desa Tempuran Berdasar Jenis Pekerjaan

\begin{tabular}{|l|l|l|l|}
\hline No. & \multicolumn{1}{|c|}{ Jenis Pekerjaan } & \multicolumn{1}{|c|}{ Laki-laki } & \multicolumn{1}{|c|}{ Perempuan } \\
\hline 1 & Petani & 1574 orang & 1564 orang \\
\hline 2 & Buruh Tani & 20 orang & 24 orang \\
\hline 3 & Buruh Migran & 12 orang & 9 orang \\
\hline 4 & Pegawai Negeri Sipil & 12 orang & 2 orang \\
\hline 5 & Peternak & 19 orang & - \\
\hline 6 & TNI & 2 orang & - \\
\hline 7 & Pedagang Keliling & 9 orang & - \\
\hline 8 & Wiraswasta & 251 orang & 123 orang \\
\hline 9 & Perangkat Desa & 12 orang & 3 orang \\
\hline 10 & Driver & 17 orang & - \\
\hline
\end{tabular}

(Sumber: dokumentasi dari profil Desa Tempuran 2019)

Berdasar data demografis, Desa Tempuran memiliki indikator sebagai potensi masyarakat yang rawan termaginalkan terutama pada demensi ekonomi. Hal ini didasarkan pada keadaan desa yang didominasi oleh penduduk dengan tamatan pedidikan sekolah dasar dan kebanyakan berkecimpung dalam bidang pertanian. Keadaan penduduk desa yang demikian, selaras dengan konsep yang dikemukakan Alfitri (dalam Auldina, 2018:3) yang menyatakan bahwa masyarakat marginal memiliki perjuangan pada tiga demesi yaitu demensi ekonomi, politik dan administrasi publik, serta demensi kemudahan fisik yang terhalang karena keterbatasan dalam aksesbilitas. Pada demensi ekonominya masyarakat Desa Tempuran sulit untuk melakukan perkembangan disebabkan perekonomiannya diikutkan pada perkembangan hasil pertanian diamana siklus pertanian mengikuti iklim cuaca yang tidak menentu. Dalam hal politik dan administrasi publik masyarakat Desa Tempuran cenderung mengikuti dinamika dari penyelenggaraan pemerintahan. Sedangkan dalam kemudahan aksesbilitas secara fisik dipengaruhi geografis desa berupa pegunungan, jauh dai peradaban kota sehingga sulit untuk menjangkau pelayanan publik seperti kesehatan, serta jalan desa yang rusak menyebabkan lambatnya perkembangan mobilitas perekonomian.

Tiga demensi perjuangan masyarakat marginal Desa Tempuran tersebut memiliki titik temu dengan lingkup pembangunan desa diamana lingkup pebangunan menjadi wadah bagi masyarakat untuk menacapi tujuan atas apa yang diperjuangkan alam demensi-demensi perjuangnnya. Berikut ini titik temu Tiga demensi perjuangan masyarakat marginaldengan lingkup pembangunan desa: 


\section{REFORMASI}

ISSN 2088-7469 (Paper) ISSN 2407-6864 (Online)

Volume 10 Nomor 1 (2020)

1. Demensi ekonomi dalam pembangunan desa, termuat pada kegiatan bidang pemberdayaan masyarakat desa dan bidang pembangunan desa yang tranformasinya berdasar RPJMDes dan RKPDes.

2. Demensi politik dan administrasi publik dalam pembangunan desa tercermin pada lingkup bidang pembinanaan masyarakat desa dan bidang penyelenggaraan pemerintahan desa.

3. Demensi kemudahan fisik yang terhalang karena keterbatasan dalam aksesbilitas, mendapat tawaran solusi melalui lingkup bidang pembangunan desa dalam segi sarana dan prasarana infrastruktur, kesehatan, pendidikan dan ekonomi.

(Sumber: Permendagri Nomor 114 Tahu 2014 tentang Pedoman Pembangunan Desa).

Titik temu tersebut secara tidak langsung menjadi paradigma atau kacamata bagi segenap pihak dalam menjalankan inklusi sosial dalam pembangunan desa, baik dalam maksud menjadikan dan menguatkan masyarakat sebagai subjek pembangunan desa maupun dalam hal mengikis marginalisasi masyarakat (eksklusi sosial).

Pada demensi ekonomi dalam pembangunan desa yang terdapat pada Desa Tempuran, berdasarkan wawancara bersama Kepala Desa Tempuran yaitu Bapak Tri wahyono dan beberapa warga Desa Tempuran, ditemukan data bahwa kekuatan ekonomi masyarakat Desa Tempuran berporos pada sektor pertanian, pasar desa, dan home industry (industri rumahan) dengan kommoditas produk berupa besek. Industri rumahan berupa produk karya terapan dalam wujud besek tersebut merupakan kegiatan yang dilakukan oleh kalangan ibu-ibu rumah tangga yang proses produksinya dilakukan pada rumah masing-masing, kemudian dikumpulkan pada satu rumah warga untuk memudahkan pembelian bagi pengepul atau customer (pelanggan). Dukungan pemerintah desa dalam demensi ini diantaranya adalah renovasi atau perbaikan pasar desa dan memobilisasi jaringan pemasaran produk home industry dari masyarakat desa.

Pada demensi politik dan administrasi publik dalam pembangunan desa, melalui wawancara bersama Kepala Desa Tempuran yaitu Bapak Tri Wahyono dan Bhabinkamtibmas DesaTempuran yaitu Bapak Haris Fauzi, diperoleh data bahwa Pemerintah Desa Tempuran menjadi sentral bagi masyarakat desanya, dan masyarakat desa berperan sebagai partisipan yang memanfaatkan dan memperoleh manfaat. Dalam demensi ini masyarakat Desa Tempuran memproleh peranan sebagai partisipan pada forum-forum proses pembuatan RPJMDes atau RKPDes, serta dalam programprogram lainnya seperti pemilu berdasar arahan dan binaan dari Pemerintah Desa Tempuran dan Bhabinkamtibmas Desa Tempuran. Sedangkan manfaat secara administratif yang diperoleh masyarakat dari Pemerintah DesaTempuran adalah layanan pembuatan surat-menyurat yang diwenangi oleh Pemerintah Desa.

Pada demensi kemudahan fisik yang terhalang karena keterbatasan dalam aksesbilitas, berdasar hasil observasi lapangan, menemukan data bahwa masih terdapatnya halangan bagi masyarakat. Halangan yang terjadi dalam demensi ini yaitu Pasar Ngagik sebagai pasar di Desa Tempuran memiliki keadaan kurang terawat, dalam observasi menemukan bahawa pasar tersebut masih mengalami rekonstruksi, namun pelaksanaannya melambat. Sarana dan prasarana kesehatan desa seperti rumah sakit tidak ada melainkan sebatas puskesmas yang jarang aktif, namun pihak pemerintah desa menjalin kerjasama dengan beberapa tenaga ahli kesehatan untuk melakukan penyuluhan kesehatan. Selain itu keadaan jalan desa yang juga berfungsi memobilisai dinamika perekonomian warga, mengalami rekonstruksi yang lambat.

Berdasarkan data lapangan diatas, baik dari hasil wawancara serta observasi, menunjukkan inklusi sosial yang dijalankan dalam pembangunan Desa Tempuran adalah kebijakan pembangunan membawa masyarakat untuk inklusi (terlibat) dalam pembangunan desa yang mengarah pada 


\section{REFORMASI}

ISSN 2088-7469 (Paper) ISSN 2407-6864 (Online)

Volume 10 Nomor 1 (2020)

pemenuhan hak masyarakat, ekonomi masyarakat, kepartisipasian masyarakat, dan pemberdayaan masyarakat. Namun terdapat kendala berupa kelambatan rekonstruksi sarana dan prasarana yang mewadahi demensi kemudahan fisik yang terhalang karena keterbatasan dalam aksesbilitas serta tidak ada pembaharuan atau inovasi yang dikembangkan dalam komoditas home industry (Industri Rumahan)masyarakatnya, hal tersebut berimbas pada tidak maksimalnya capaian inklusi sosial dalam pembangunan desa yang dilakukan masyarakat Desa Tempuran.

\section{KESIMPULAN}

Inklusi sosial dalam pembangunan desa merupakan nilai yang mengarahkan masyarakat kepada dua bentuk pergerakan, yaitu pergerakan masyarakat sebagai subjek pembangunan secara regulatif berdasar undang-undang dan pergerakan masyarakat sebagai subjek yang mengikis marginalisasinya. Antara keduanya saling berkaitan dimana posisi masyarakat sebagai subjek yang mengikis marginalisasinya merupakan bagian integral dari peranan masyarakat dalam menjadi sebagai subjek pembangunan berdasar yuridis formalnya.

Inklusi sosial memiliki keterkaitan dengan penegakkan HAM, pemberdayaan masyarakat, dan partisipasi masyarakat, namun penekanan inklusi sosial mengarah pada masyarakat rawan marginal. Masyarakat marginal adalah masyarakat yang memiliki perjuangan akibat keterbatasannya pada demensi ruang publik, ekonomi, dan juga aksesbilitas layanan umum, serta hal-hal lain yang menjadi haknya. Disandingkan dengan pembangunan desa, demensi tersebut menjadi demensi perjungan bagi masyarakat desa dalam peranannya sebagai subjek pembangunan desa.

Berdasar data lapangan inklusi sosial yang dijalankan dalam pembangunan Desa Tempuran adalah kebijakan pembangunan membawa masyarakat untuk inklusi (terlibat) dalam pembangunan desa yang mengarah pada pemenuhan hak masyarakat, ekonomi masyarakat, kepartisipasian masyarakat, dan pemberdayaan masyarakat, namun terkendala oleh kelambatan rekonstruksi sarana dan prasarana serta tidak ada pembaharuan atau inovasi yang dikembangkan dalam komoditas home industry (Industri Rumahan)masyarakatnya, hal tersebut berimbas pada tidak maksimalnya capaian inklusi sosial dalam pembangunan desa yang dilakukan masyarakat Desa Tempuran.

\section{DAFTAR PUSTAKA}

Arum, L. Y. (2019). Implementasi Kebijakan Pemerintah Dalam Perencanaan Pelebaran Jalan Patunas Pelabuhan Roro Kabupaten Tanjung Jabung Barat.

Auldina, L. (2018). Marginalisasi Pendidikan Di Daerah Perbatasan ( Studi Kasus Di Desa Mapur Kecamatan Bintan Pesisir Kabupaten Bintan Provinsi Kepulauan Riau ), (2006), 1-20.

Dadan Rohimat, Rita Rahmawati, G. G. S. (2017). Partisipasi Masyarakat Dalam Implementasi Program Kotaku / Pnpm Di Kecamatan Ciawi, 3, 71-80.

Fahadi, P. R. (2020). Karier Subkultur Dan Kelompok Marginal : Menelaah Potret Profesi Dominatrix Dalam Serial Netflix “ Bonding," 9(2019).

Fitrah, N. (2017). Problematika Pelaksanaan Musyawarah Rencana Pembangunan Desa (Musrenbang Desa) Studi Kasus Desa Rumpa Kecamatan Mapilli.

Henra Natalia Silaban, A. H., \& Setiawan, R. (2016). Efektivitas Dinas Pekerjaan Umum Dalam Pelaksanaan Pengawasan Pemeliharaan Jalan Kota Di Kota Tanjungpinang, 1-24.

Kushandajani, F. A. N. Dan. (2019). Partisipasi Politik Masyarakat Kecamatan Medan Maimun Pada Pemilihan Gubernur Sumatera Utara Tahun 2018 Political Participation Medan Maimun District Community At Election Governor North Sumatra Year 2018, 7(2), 227-235.

Maftuhin, A. (2017). Mendefinisikan Kota Inklusif: Asal-Usul, Teori Dan Indikator, 93-103. Https://Doi.Org/10.14710/Tataloka.19.2.93-103 


\section{REFORMASI}

ISSN 2088-7469 (Paper) ISSN 2407-6864 (Online)

Volume 10 Nomor 1 (2020)

Ningrum, D. F. (2019). Kegiatan Inklusi Sosial Di Perpustakaan Ganesha Sma N 1 Jetis Bantul, 10(2), 123-131. Https://Doi.Org/10.20885/Unilib.Vol10.Iss2.Art9

Simarmata, R. (2017). Perspektif Inklusi Sosial Dalam Uu Nomor 6 Tahun 2014 Tentang Desa:

Kebijakan Dan Tantangan Implementasi. Transformasi Sosial, 7-27.

Walmi Sholihat, R. N. S. Dan V. R. (2017). Analisis Pengelolaan Alokasi Dana Desa Di Kecamatan Seberida Kabupaten Indragiri Hulu, 25(6), 15-29.

Yulisnaini, E. (2018). Peran Komunitas Young Voices Dalam Pemberdayaan Disabilitas Di Kota Banda Aceh.

Republik Indonesia. 2014. Undang-Undang Nomor 6 Tahun 2014 Tentang Desa. Lembaran Negara Republik Indonesia Tahun 2014 Nomor 7. Jakarta. Sekretariat Negara Republik Indonesia.

Republik Indonesia. 2014. Peraturan Menteri Dalam Negeri Republik Indonesia Nomor 114 Tahun 2014 Tentang Pedoman Pembangunan Desa. Berita Negara Republik Indonesia Tahun 2014 Nomor 2094. Jakarta. 